\title{
UPAYA PEMELIHARAAN KESEHATAN PADA KORBAN BANJIR ROB
}

\author{
Nurul Khasanah ${ }^{1)}$, Artika Nurrahima ${ }^{2)}$ \\ ${ }^{1,2)}$ Departemen Ilmu Keperawatan Universitas Diponegoro \\ Jl. Prof.H.Soedarto S.H, Tembalang, Kec. Tembalang, Kota Semarang, Jawa Tengah 50275 \\ Email: artikanurrahima@fk.undip.ac.id
}

\begin{abstract}
The North Semarang region has a very high frequency of tidal flooding. Therefore, it is very necessary to maintain health for victims of tidal flooding. Health care efforts are useful to anticipate, and prevent health problems that may occur afterward. Previous research was still limited to address medication problems so that this study performed preventive health care efforts. This study aims to explore the experience of tidal flooding victims related to their health care efforts in Terboyo Wetan Village, District of Semarang Genuk, in 2019. This qualitative research was combined with a qualitative descriptive approach. Semi-structured in-depth interviews were further employed. The samples of this research were five participants selected using purposive sampling technique. Then, the data were analyzed by a method, namely thematic analysis. This study identified three themes, which include: (1) The impact of tidal flooding experienced by the community, (2) Health care efforts for victims of tidal flooding, and (3) Health services during tidal flooding. Health care efforts that have not been maximized are efforts to prevent the emergence of health problems due to tidal flooding as indicated by the limited use of boots, and inappropriate manners in maintaining sanitation, and health. Those can be observed from only a few participants who cleaned the house, and the environment properly. The efforts done by the participants are still considered less appropriate in preventing the spread of disease. In other words, health care efforts at the prevention stage have not been yet effective although the treatment stage has been already optimal. At last, to conduct further research regarding the factors that influence health care efforts for victims of tidal floods is also expected in the future.
\end{abstract}

Keywords: tidal flooding, health care, experience

\section{LATAR BELAKANG}

Wilayah Semarang Utara merupakan daerah yang rawan terkena dampak kenaikan muka air laut. Dampak yang paling utama diakibatkan oleh kenaikan muka air laut adalah terjadinya banjir pasang (Handoyo, Suryoputro, Subardjo, 2016). Badan Penanggulangan Bencana Daerah (BPBD) Kota Semarang, menunjukkan bahwa terdapat 117 kejadian bencana yaitu bencana banjir, rob, tanah longsor, kekeringan, puting beliung, perubahan iklim dan gelombang pasang/abrasi pada rentang 1990-2015 (BPBD, 2015). Hampir seluruh kelurahan di Kecamatan Semarang terkena dampak dari banjir rob dengan total luas genangan rob sebesar 823.545 ha pada tahun 2015 (Widya, Suhartono dan Budiyanto, 2018).

Banjir rob telah menyebabkan terjadinya kerusakan rumah, infrastruktur jalan, fasilitas umum seperti sekolah dan layanan kesehatan, sanitasi, lahan pekarangan, tegalan, persawahan dan lahan tambak (Marfai, 2014). Selain itu, banjir rob dapat menyebabkan timbulnya berbagai penyakit bahkan bisa menimbulkan wabah (Kemenkes RI, 2013). Data laporan pengendalian penyakit Kementerian Kesehatan Republik Indonesia (Kemenkes RI) menunjukkan bahwa ada 7 penyakit yang sering muncul pada bencana banjir yaitu, leptospirosis, diare, penyakit saluran pencernaan, infeksi saluran pernapasan atas, tifoid, penyakit kulit dan demam berdarah atau malaria (Harthan dan Oedjo, 2014).

Masalah kesehatan yang dialami masyarakat ketika banjir yaitu kesulitan air bersih, sanitasi lingkungan, terserang penyakit, persediaan bahan makanan dan pelayanan kesehatan (Meinisa, 2017). Perilaku pemeliharaan kesehatan merupakan perilaku atau usaha-usaha seseorang untuk memelihara atau menjaga agar tidak sakit dan usaha untuk penyembuhan bilamana sakit (Octastefani, Wahyuni, Rum dan Fitrah, 2018). Menurut penelitian Meinisa (2017) menyebutkan pola tindakan dalam mengatasi masalah kesehatan ketika situsi banjir diantaranya memilih pengobatan modern dan pengobaan tradisional, meminta bantuan yang lebih sering kepada tetangga/orang-orang terdekat di sekitar rumahnya, menjual barang/simpanan hasil panen dan hewan ternak, berhutang. Hasil studi pendahuluan yang dilakukan peneliti dengan wawancara terhadap 2 orang yang mengalami banjir rob, didapatkan hasil bahwa satu partisipan mengatakan upaya untuk mengatasi masalah kesehatannya memilih untuk membiarkan saja. Sedangkan partisipan kedua mengatakan upaya yang dilakukan lebih memilih mengobati dengan bahan alami seperti minyak kelapa dan tidak memeriksakan ke pelayanan kesehatan. Hal ini dapat menunjukkan perilaku memelihara kesehatan yang dilakukan partisipan kurang efektif karena kurang menunjukkan perilaku sehat. Berdasarkan fenomena tersebut peneliti meneliti upaya pemeliharaan kesehatan pada korban banjir rob.

\section{METODE}

Penelitian ini merupakan jenis penelitian deskriptif kualitatif. Teknik pengambilan sampel yang digunakan adalah purposive sampling sesuai kriteria inklusi yaitu partisipan yang pernah mengalami banjir rob $\geq 3$ kali. 
Kriteria eksklusi dalam penelitian ini adalah partisipan tidak mampu berkomunikasi secara verbal maupun non verbal karena faktor psikologis, masalah kognitif atau keterbatasan fisik. Jumlah sampel sebanyak 5 partisipan. Pengambilan data dilakukan dengan wawancara mendalam semi struktur. Uji keabsahan data menggunakan teknik membercheck. Pengambilan data dilakukan pada bulan Mei sampai Juni 2019. Analisis data menggunakan analisis tema. Penelitian ini telah disetujui oleh tim Etik Penelitian Kesehatan RSI Sultan Agung dengan nomor 08/B/RSI-SA/IV/2019.

\section{HASIL PENELITIAN}

Penelitian dilakukan pada tanggal 29 Mei 2019 hingga 2 Juni 2019. Setelah dilakukan wawancara kepada lima partisipan peneliti memperoleh saturasi data. Adapun karakteristik partisipan adalah rata-rata usia partisipan 47,6 tahun. Empat dari lima partisipan termasuk kategori dewasa menengah, sedangkan satu partisipan merupakan lansia. Terdapat empat partisipan berjenis kelamin perempuan dan satu partisipan berjenis kelamin laki-laki. Mayoritas partisipan bekerja sebagai ibu rumah tangga. Sebanyak dua partisipan memiliki tingkat pendidikan SD, dua dari lima partisipan memiliki tingkat pendidikan SMA dan satu dari lima partisipan memiliki tingkat pendidikan SMK.

Hasil analisa data diperoleh tiga tema yaitu dampak banjir rob yang dialami oleh masyarakat, upaya pemeliharaan kesehatan korban banjir rob, dan pelayanan kesehatan saat bencana rob.

Dampak banjir rob yang dialami masyarakat

Dampak banjir rob yang dialami masyarakat pada penelitian ini meliputi dampak psikologis, dampak fisik, dampak ekonomi, dan dampak kesehatan. Sebanyak dua dari lima partisipan mengungkapkan perasaan sedih dan panik. Berikut ungkapan partisipan tersebut.

"Tiba-tiba datang sendiri mbak ditambah hujan deras, sedih mbak, panik juga mbak, susah mau apaapa nggak bisa" (P1)

"Ya sedih mbak, saya tinggalkan rumah ini ngungsi ditempat anak saya” (P2)

Lima partisipan mengalami dampak fisik berupa kerusakan pada bangunan tempat tinggal, peralatan dapur dan kendaraan bermotor. Berikut ini ungkapan dari partisipan tersebut.

“...terus beberapa peralatan rumah, alat dapur juga pada rusak mbak..” (P1)

" Rusak kabeh mbak sing ora tau melu rusak malah melu rusak mbak, ini rumah saya juga rusak ambles dikit mbak...” (P2)

“..Mau naik motor malah mogok mbak cepet rusak mbak..” (P3)

“....rumah jadi berantakan” (P4)

“....disini termasuk rendah mbak jadi air langsung masuk” (P5)

Sebanyak tiga dari lima partisipan mengalami dampak ekonomi berupa tidak bisa bekerja, tidak bisa kemanamana dan mengalami kerugian. Berikut ungkapan partisipan:
"Susah cari ekonomi..nggak bisa kemana-kemana, keluar juga nggak bisa.....susah kerja suami saya mbak...” (Pl)

"...Sedih mbak nggak bisa jualan.. bener-bener terganggu mbak” (P3)

"Ya susah mbak nggak enak, rugi juga mbak termasuk ekonomi juga susah......” (P4)

Sebanyak lima partisipan mengungkapkan terdapat beberapa penyakit yang muncul akibat banjir rob seperti penyakit kulit, penyakit saluran pencernaan, infeksi saluran pernapasan atas dan demam. Berikut penuturannya:

“...penyakit kayak gatal-gatal, kutu air” (P1)

"Masuk angin mbak, mules-mules gitu” (P2)

"Kebanyakan ya gatal-gatal, kutu air...batuk pilek” (P3)

"Lahan kumuh mbak menyebabkan penyakit anakanak seperti gatal-gatal, kalau anak-anak biasanya kan kecek ya mbak bisa panas gitu” (P4)

"Gatal-gatal terus kutu air....demam.." (P5)

Upaya pemeliharaan kesehatan korban banjir rob

Upaya pemeliharaan kesehatan yaitu upaya untuk mencegah, mengobati/merawat bilamana sakit dan meningkatkan derajat kesehatan, upaya tersebut meliputi : pencegahan oleh klien dan keluarga, pengobatan dan harapan masyarakat terhadap kejadian banjir rob. Sebanyak dua dari lima partisipan menggunakan sepatu boots saat banjir rob. berikut ungkapan partisipan:

"bisa pakai sepatu boots..” (P1)

“....kalau masih rob mau keluar ya pakai sepatu boots mbak" (P4)

Sebanyak empat dari lima mengatakan menjaga kebersihan dan kesehatan dengan cara cuci tangan dan kaki bersih tanpa sabun dan mengkonsumsi air putih. Berkut penuturannya:

“..cuci tangan dan kaki bersih mbak..saya cuci pakai air tok.. terus minum air putih hangat..” (P1)

“...cuci tangan kaki..minum air putih yang banyak sih mbak...” (P2)

“...yang penting jaga kesehatan juga kebersihan mbak....”(P4)

Upaya pencegahan dengan membersihan rumah dan lingkungan dilakukan oleh empat partisipan dari lima partisipan. Berikut ungkapan partisipan:

“...nyapu, di pel pakai pembersih lantai, menyediakan tempat sampah, membuang sampah di tempat sampah, membersihkan selokan mbak kalau ada sampah ya dibuang di tempat sampah..." (P1)

".....tetap menjaga kebersihan mbak harus cepet-cepet dibersihkan, membuang sampah ke tempat sampah” (P3)

"Ya paling ndak sampah-sampah dibersihkan dijadikan satu terus dibuang gitu mbak..” (P4)

“....bersih-bersih rumah sampah diambilin...." (P5)

Sebanyak empat dari lima partisipan mengungkapkan mencegah penyebaran penyakit dengan cara hanya diusir saja, disiram memakai air dibersihkan,lebih 
waspada, dan memakai obat tikus. Berikut penuturannya:

"Biasanya langsung saya kasih air yang banyak mbak..terus..diusir, saya buang ke tempat sampah..saya bersihkan lagi pakai pembersih lantai" (P1)

"Ya tikusnya langsung ilang mbak pergi sendiri.langsung saya bersihin lingkungan rumah saya. Disiram pakai air yang banyak mbak "(P2)

"....hewan seperti ular itu lumayan banyak mbak... lebih wasapada lagi sih mbak..” (P4)

“...Ya saya obati saja obat tikus itu..” (P5)

Sebanyak tiga dari lima partisipan melakukan pengobatan modern seperti pergi ke dokter dan puskesmas. Adapun ungkapan partisipan sebagai berikut:

"Ya ke dokter mbak..." (P2)

"Dikasih salep mbak dari Puskesmas...” (P3)

“....saya periksain ke Puskesmas terus dikasih salep mbak...” (P4)

Sementara dua dari lima partisipan melakukan pengobatan kombinasi yaitu pengobatan modern dan tardisional seperti diberi obat dari posyandu dan melakukan kerokan, salep dari puskesmas dan merebus daun sirih. Berikut ungkapannya:

“...terus saya keriki mbak kalau nggak ke posyandu nanti dikasih obat mbak” (P1) (keriki : Kerokan)

"Saya dikasih salep buat gatal-gatalnya..kalau nggak ya dikasih itu lho daun sirih direbus nanti airnya bisa mengurangi gatal-gatal. Kalau nggak ya buat mandi itu kan bisa" (P5)

Sebanyak empat dari lima partisipan mengatakan bahwa harapan masyarakat terhadap kejadian banjir adalah perbaikan lingkungan. Berikut ungkpaan partisipan:

“..selalu waspada aja..berharap rob tidak masuk kerumah lagi..selalu jaga kesehatan, kebersihan juga mbak...” (P1)

"ya sebisa mungkin jangan ada rob lagi mbak..rumah-rumah disini ya beberapa sudah dinaikkan sih mbak...(P2)

"ya alhamdulillah sudah dibangun pompa air besar mbak..kalau rob dateng nggak banjir rob lagi mbak soalnya dah ada pompa air besar itu.." (P3)

" harapnnya ya seperti ini sudah ditinggikan diperbaiki, ada pompa air besar...” (P4)

Pelayanan kesehatan saat bencana rob

Pelayanan kesehatan sangat diperlukan masyarakat ketika banjir rob. Semua partisipan mengatakan pelayanan kesehatan saat banjir rob meliputi peran petugas kesehatan dan hambatan ke pelayanan kesehatan. Sebanyak dua dari lima partisipan mendapatkan pemeriksaan kesehatan secara gratis dari puskesmas. Berikut penuturanya:

“...tapi kemaren ada juga yang diperiksa mbak...." (P3)

"Biasanya ada petugas puskesmas yang keliling itu.. gratis periksanya” (P5)
Sebanyak lima partisipan mendapatkan bantuan makanan berupa mie instan saat banjir rob. Berikut ungkapan partisipan:

“....dikasih bantuan kayak mie instan gitu mbak” (P1)

"...dikasih makanan kayak mie instan gitu mbak...”(P2)

“...Kemaren ada bantuan makanan aja sih mbak.." (P3)

“...kalau banjir rob dikasih makanan kayak mie instan.. (P4)

“...kalau rob ya biasanya dikasih bantuan makanan mie instan...” (P5)

Satu dari partisipan memperoleh pengetahuan tentang kesehatan melalui penyuluhan dari PKK. Berikut ungkapan partisipan:

"Di PKK mbak ada....Sosialisasinya tentang kesehatan mbak, bagaimana cara membersihkan rumah....(P1)

Sebanyak tiga dari lima partisipan mengatakan terdapat tida hambatan ke pelayanan kesehatan yaitu banjir rob, macet dan jarak yang jauh. Berikut penuturannya:

"Puskesmasnya kan di Genuk mbak ya susah juga kan kena rob juga disitu.jauh mbak..terus macet.." (P1)

“..kalau mau dipuskesmas lumayan jauh mbak..” (P2)

“..Ya robnya itu yang menghambat susah..macet lagi”, (P5)

\section{PEMBAHASAN}

Dampak banjir rob yang dialami oleh masyarakat meliputi dampak psikologis, dampak fisik, dampak ekonomi, dan dampak kesehatan. Respon masyarakat dalam menghadapi banjir sangat beragam, sesuai dengan pengalaman hidup yang dirasakan oleh masing-masing individu. Depresi sebagai salah satu dampak dari kondisi banjir rob yang terus menerus secara berkala dialami tampaknya menjadi satu maslaah psikologis tersendiri. Individu yang mengalami depresi menunjukan sedih dan suasana hati apatis, konsep diiri negatif, perubahan tingkat aktivitas misalnya menjadi lamban lesu atau agitas (Davidson, Neale \& Ann, 2003). Banjir rob telah menyebabkan terjadinya kerusakan bangunan tempat tempat, perabot rumah tangga dan kendaraan bermotor (Harini, Sarastika, Supriyati, Satriagasa \& Ariani, 2017). Orang-orang telah menderita kerugian ekonomi karena banjir rob yang mengurangi pendapatan dan meningkatkan pengeluaran masayarakat. Kusuma, Setyowati \& Suhandini (2016) menyebutkan bahwa rob merupakan fenomena alam yang berdampak terhadap kehidupan manusia yang salah satunya berdampak terhadap mata pencaharian. Terganggunya segala macam aktivitas masyarakat akibat terjadinya banjir rob menyebabkan perubahan sosial ekonomi bagi masyarakat yang mengalaminya (Kusuma et al., 2016). Fenomena banjir rob telah memberikan dampak negatif terhadap kawasan pemukiman pesisir diantaranya adalah kesehatan (Wahyudi, 2007). Dampak kesehatan yang dirasakan masyarakat diantaranya munculnya berbagai penyakit seperti penyakit gatal-gatal, penyakit slauran pencernaan, infeksi saluran pernapasan atas dan demam. Penelitian ini sejalan dengan penelitian Faiqoh, Sulistiyani \& Budiyono 
(2017) menyebutkan bahwa dampak kesehatan yang dirasakan oleh masyarakat di Kota Semarang diantaranya penyakit gatal-gatal dengan persentase $84,44 \%$, penyakit gangguan pencernaan dengan persentase $71,11 \%$ dan penyakit demam tifoid dengan persentase $51,11 \%$ (Gultom, Juhadi \& Ananto, 2018). Selain itu, kondisi air genangan yang semakin tinggi dan waktu gennagan yang lama akan berpengaruh terhadap kumuhnya pemukiman warga. Penelitian lain juga menyebutkan bahwa dampak yang paling banyak dirasakan oleh masyarakat adalah lingkungan kotor akibat sampah berserakan yaitu sebanyak 100\% (Gultom et al., 2018). Kondisi lingkungan yang buruk dan sampah yang bertumpuk akan menjadi pemicu timbulnya penyakit.

Hasil penelitian menunjukkan bahwa upaya pemeliharaan kesehatan yang dilakukan korban banjir termasuk dalam tindakan preventif, dimana tujuannya untuk mencegah dan mengurangi kemungkinan terjadinya hal yang tidak diinginkan. Upaya pemeliharaan kesehatan tersebut meliputi, penggunaan sepatu boots, menjaga kebersihan dan kesehatan, membersihkan rumah dan lingkungan, mencegah penyebaran penyakit, melakukan pengobatan dan perbaikan lingkungan. Hal-hal yang perlu dilakukan saat dan setelah banjir rob adalah memaksimalkan penggunaan alat pelindung diri, seperti sepatu boots, sarung tangan karet, masker dan kacamata pelindung (Kemenkes RI, 2018). Alat pelindung diri ini berfungsi agar warga terhindar dari penyakit yang timbul dari adanya bencana banjir rob seperti infeksi jamur kulit, atau penyakit dari luka benda tajam dan penyakit lainnya. Perilaku hidup yang kurang sehat dapat menurunkan status kesehatan seseorang. Hal ini yang dilakukan oleh partisipan bahwa partisipan hanya melakukan cuci tangan dan kaki dengan air tanpa sabun. Penelitian ini sejalan dengan penelitian Harthan \& Oedjo (2014) yang menunjukkan bahwa selama banjir lebih banyak warga yang tidak mempraktikkan perilaku hidup bersih dan sehat karena belum menyadari manfaatnya dalam kondisi darurat atau bencana. Selain itu, Upaya pencegahan lain dapat dilakukan setelah pasca banjir rob diantaranya membersihkan rumah dan lingkungan dengan cara menyapu lantai, mengepel lantai menggunakan pembersih lantai, menyediakan tempat sampah dan membuang sampah di tempat sampah. Semakin tinggi genangan air banjir rob dan semakin lama banjir rob maka akan mengakibatkan semakin lama partisipan untuk kontak dengan air genangan akibat banjir rob tersebut. Hal ini bisa saja bakteri seperti leptospira yang berada pada genangan air pada saat banjir rob tersebut dapat masuk ke dalam tubuh jika bagian tubuh tersebut terendam lama pada air yang terinfeksi yaitu masuk melalui luka atau pori-pori (CDC, 2012).

Upaya pemeliharaan kesehatan yang lain adalah melakukan pengobatan. Pada penelitian ini pengobatan terdiri dari dari pengobatan modern dan pengobatan kombinasi (modern dan tradisional). Penelitian ini menunjukkan bahwa mayoritas memilih pengobatan modern sebanyak tiga partisipan sedangkan pengobatan tradisional sebanyak dua partisipan. Pengobatan modern atau medis merupakan cara yang dilakukan masyarakat dalam upaya penyembuhan, pencegahan dan pemulihan penyakit dengan menggunakan produk atau alat. Partisipan memanfaatkan fasilitas pengobatan gratis dari puskesmas. Hal inilah yang mempengaruhi partisipan yang lebih banyak memilih pengobatan modern daripada pengobatan tradisional karena pengobatan ini tidak membutuhkan biaya dan sarana transportasi untuk menjangkau tempat pengobatan. Tempat pengobatan dilakukan dipemukiman warga sehingga memudahkan untuk pergi berobat. Sedangkan untuk pengobatan tradisional bisa berupa membuat ramuan sendiri seperti yang di ungkapkan oleh partisipan kelima bahwa pengobatannya bisa menggunakan daun sirih yang direbus dan partisipan pertama melakukan kerokan. Upaya-upaya yang dilakukan oleh masyarakat tersebut menyimpan banyak harapan seperti perbaikan lingkungan dan tidak ada lagi banjir rob. Namun, dalam mewujudkan harapan tersebut masyarakat masih terdapat beberapa hambatan. Hambatan tersebut merupakan hasil kerusakan yang diakibatkan oleh rob, yang datangnya bukan diinginkan oleh masyarakat. Hal ini berkaitan dengan teori hambatan perilaku yang disampaikan Fisher et al dalam Alvin (1999) yang menyatakan, stimulasi berlebihan atau tidak diinginkan mendorong terjadinya hambatan dalam kapasitas pemprosesan informasinya, akibatnya orang merasa kehilangan kotrol terhadap situasi yang sedang berlangsung.

Berbagai upaya pemeliharaan kesehatan/pencegahan yang dilakukan korban banjir rob ini diperlukan pelayanan kesehatan saat banjir rob. Penelitian ini di dukung oleh penelitian Widya et al. (2018) yang menunjukan bahwa gambaran aspek kesehatan meliputi jenis pelayanan kesehatan yang dimanfaatkan oleh responden ketika sakit adalah puskesmas (91,3\%), 63 responden mengatakan memiliki asuransi kesehatan dimana mayoritas memiliki BPJS $(60,9 \%)$. Mayoritas masyarakat memilih puskesmas yang dimanfaatkan ketika sakit, sehingga peran petugas kesehatan sangat diperlukan oleh korban banjir rob. Hasil penelitian ini menemukan tiga temuan peran petugas kesehatan saat banjir rob yaitu pemeriksaan kesehatan, bantuan makanan dan penyuluhan kesehatan.

Peran petugas kesehatan pada saat bencana diantaranya melakukan penilaian cepat kesehatan, memberikan pelayanan kesehatan (memberikan pertolongan pertama dan melakukan pemeriksaan kesehatan), mengirimkan perbekalan kesehatan ke lokasi, mengaktifkan unit pelayanan kesehatan dan membuat pos kesehatan dilokasi (Widayanto, 2013). Peran petugas yang lainnya yaitu pemberian bantuan makanan untuk meminimalisir gizi buruk yang mungkin timbul (Zulqa, Herawati \& Hardjanto, 2017). Namun pada penelitian ini pemberian makanan berupa mie instan dirasa masih kurang dan belum mememuhi gizi yang baik, sehingga petugas kesehatan perlu memperhatikan lagi dalam penyaluran bantuan makanan. Selain itu, penyuluhan kesehatan juga perlu dilakukan oleh petugas kesehatan, guna untuk meningkatkan pengetahuan dan kesadaran pada korban banjir rob. Penyuluhan kesehatan termasuk dalam tindakan promotif yang bertujuan untuk 
meningkatkan pengetahuan dan kesadaran masyarakat untuk melakukan Perilaku Hidup Bersih dan Sehat (PHBS) (Kemenkes RI, 2018). Hasil penelitian ini menunjukkan hanya satu partisipan yang mendapatkan penyuluhan kesehatan. Hal ini dapat menunjukan tingkat pengetahuan dan kesadaran tentang perilaku hidup bersih dan sehat masih kurang. Program tersebut perlu ditingkatkan lagi guna menyadarkan pentingnya mengupayakan Perilaku Hidup Bersih dan Sehat (PHBS). Hal ini sejalan dengan penelitian Ardiansyah \& Rahmantari (2013) bahwa penyuluhan dan praktik PHBS (Perilaku Hidup Bersih dan Sehat) guna mewujudkan masyarakat desa peduli sehat dan penyuluhan ini dapat disosialisasikan serta diterapkan dalam kehidupan seharihari masyarakat secara kontinyu. Selain itu, Semakin lama air genangan rob maka akan makin susah melakukan aktivitas termasuk dampak buruk terhadap kesehatan. Individu tidak bisa pergi berobat karena banjir rob, ditambah lagi di jalan-jalan utama menyebabkan kemacetan. Selain itu jarak ke pelayanan kesehatan dipenelitian ini lumayan jauh, sehingga alasan tersebut dijadikan masyarakat enggan pergi berobat dan lebih memilih membiarkan saja atau menunggu ada pemeriksaan gratis di lokasi tersebut.

\section{KESIMPULAN DAN SARAN}

Upaya pemeliharaan kesehatan yang belum maksimal adalah upaya pencegahan terhadap timbulnya masalah kesehatan akibat rob yang ditunjukkan dengan terbatasnya penggunaan sepatu boots, perilaku tidak tepat dalam menjaga kebersihan dan kesehatan, tidak semua partisipan membersihkan rumah dan lingkungan dengan benar, upaya yang dilakukan partisipan masih kurang tepat dalam mencegah penyebaran penyakit. Upaya pemeliharaan kesehatan pada tahap pencegahan masih belum efektif sedangkan tahap pengobatan sudah optimal. Diperlukan penelitian selanjutnya tentang faktor-faktor yang mempengaruhi upaya pemeliharaan kesehatan korban banjir rob.

\section{Daftar Pustaka}

Alvin, F. H. (1999). Beberapa teori psikologi lingkungan. Buletin Psikologi, 7(2),7-19.

Ardiansyah, Y., Rahmantari, D. N. (2013). Penyuluhan dan praktik PHBS (Perilaku Hidup Bersih dan Sehat) dalam mewujudkan masyarakat Desa Peduli Sehat. Jurnal Inovasi dan Kewirausahaan, 2(1), 5-50.

Badan Penanggulangan Bencana Daerah Kota Semarang. (2015). Laporan kegiatan pengkajian, verifikasi dan rekonstruksi pasca bencana Kota Semarang. Diakses pada 13 September 2018, dari: bpbd.jatengprov.go.id

CDC. (2012). Leptospirosis. Atlanta: Centers for Diseases Control and Prevention.

Davidson, C. G., Neale, M. J., \& Ann, M. K. (2003). Psikologi abnormal. Edisi Kesembilan. Penerjemah: Fajar Nurmalasari. Jakarta: PT Raja Grafindo Persada.
Faiqoh, F., Sulistiyani \& Budiyono. (2017). Analisis hubungan tingkat kerentanan penduduk wilayah pantai Kota Semarang akibat banjir rob dengan status kesehatan. Jurnal Kesehatan Masyarakat, 5(5), 649-658

Gultom, H. T., Juhadi \& Ananto, Aji. (2018). Fenomena banjir rob di Kota Semarang sebagai sumber belajar. Jurnal Pendidikan Geografi, 6(3), 198205.

Handoyo, G., Suryoputro, A. A. D., \& Subardjo, P. (2016). Genangan banjir rob di Kecamatan Semarang Utara Gentur. Review literatur: Jurnal Kelautan Tropis, 19(1), 55-59.

Harini, R., Sarastika, T., Supriyati, Satriagasa, M. C., \& Ariani, R. D. (2017). The survival strategy of households affected by tidal floods: the cases of two villages the Pekalongan coastal area. Indonesian Journal of Spatial and Regional Analysis. ISSN: 0852-0682

Harthan, T., \& Oedjo, S. (2014). Faktor determinan perilaku cuci tangan pakai sabun saat banjir Bengawan Solo di Bojonegoro. Review Literatur: Jurnal Promosi kesehatan, 2(2), 160172.

Kemenkes RI- Direktorat Penyehatan Lingkungan. (2013). Buku Panduan Penyelenggaraan kegiatan HCTPS sedunia 2013. Dirjen Pengendalian Penyakit dan Penyehatan Lingkungan.

Kemenkes RI. (2018). Ini persiapan untuk turun ke daerah bencana. Diakses pada 03 Juli 2019 dari: www.depkes.go.id

Kemenkes RI. (2018). Promosi kesehatan dalam bencana. Diakses pada 03 Juli 2019 dari: promkes.kemkes.go.id.

Kusuma, M. A., Setyowati, D. L., \& Suhandini, P. (2016). Dampak rob terhadap perubahan sosial masyarakat di Kawasan Rob Desa Bedono Kecamatan Sayung Kabupaten Demak. Journal of Education Social Studies, 5(2), 121-127.

Marfai, M. A. (2014). Dampak bencana banjir pesisir dan adaptasi masyarakat terhadapnya di kabupaten Pekalongan. Makalah dalam pekan ilmiah tahunan ikatan geografi Indonesia. Diakses pada 5 Maret 2019, dari: https://osf.io.

Meinisa, E. T. (2017). Pola tindakan dalam mengatasi masalah kesehatan masyarakat korban banjir. Jurnal sosial dan politik, 1-19

Octastefani, T., Wahyuni, H. I., Rum, M., \& Fitrah, A. A. (2018). Penanganan bencana di Lombok dan Donggala-Palu: belajar dari masyarakat di Semarang. Diakses pada 5 Maret 2019, dari: http://researchgate.net/publication/329424557.

Wahyudi, S. I. (2007). Tingkat pengaruh elevasi pasang laut terhadap banjir dan rob di kawasan Kaligawe Semarang. Rekaya Ilmu Pengetahuan dan Teknologi, 1(1), 27-34.

Widayanto, F. Z. (2013). Permasalahan kesehatan dalam kondisi bencana: Peran Petugas kesehatan dan 
partisipasi Masyarakat. Review Literatur: Jurnal Pendidikan Indonesia, 8(1), 37-52.

Widya, Y., Suhartono \& Budiyanto. (2018). Resiliensi masyarakat dalam menghadapi banjir rob di kelurahan bandarharjo kota semarang (Studi Kasus Aspek Lingkungan dan Kesehatan). Review Literatur: Jurnal Kesehatan Masyarakat, 6(1), 696-702.
Zulqa, I., Herawati, R., \& Hardjanto, U. S. (2017). Pelaksanaan tugas badan penanggulangan bencana daerah Kota Semarang berdasarkan peraturan daerah nomor 12 tahun 2010 tentang organisasi dan tata kerja badan penanggulangan bencana daerah Kota Semarang. Diponegoro Law Journal, 6(4), 1-16. 